\title{
Effect of Tin and Strontium Doping on the Photocatalytic Activity of Zinc Sulphide Nanoparticles for the Photocatalytic Degradation of Resorcinol under Solar and Ultra-Violet Light
}

\section{Bhagat MM*, Lokhande P and Mujawar HA}

Department of Chemistry, Dr. Babasaheb Ambedkar Technological University, Lonere, Raigad, Maharashtra, India

*Corresponding author: Madhuri M Bhagat, Department of Chemistry, Dr. Babasaheb Ambedkar Technological University, Lonere, Raigad, Maharashtra, India, Tel: +91 9975636701; E-mail: madhurisd16@gmail.com

Received date: February 3, 2018; Accepted date: May 18, 2018; Published date: May 25, 2018

Copyright: ( 2018 Bhagat MM, et al. This is an open-access article distributed under the terms of the Creative Commons Attribution License, which permits unrestricted use, distribution, and reproduction in any medium, provided the original author and source are credited.

\begin{abstract}
Tin (Sn) and Strontium (Sr) doped Zinc Sulphide and pure Zinc Sulphide photocatalyst have been prepared by Sol-Gel method. The prepared photocatalyst have been characterised by Thermo gravimetric Differential Thermal Analysis, Scanning Electron Microscopy, Energy Dispersive X-ray, X-Ray Diffraction, ultra-violet visible spectroscopy and photoluminescence spectroscopy. Characterization Techniques have provided information of wurtzite hexagonal structure of Zinc Sulphide. The PL spectra have shown the blue shift of Zinc Sulphide after doping it with Tin and Strontium. Photocatalytic degradation study was done by the complete degradation of an organic pollutant Resorcinol in Sun light as well as in UV-light. The factors affecting the photocatalytic activity of photocatalyst viz. $\mathrm{pH}$, catalyst loading and reuse of photocatalyst have been studied along with the photocatalytic degradation of Resorcinol. These external parameters have considerable influenced on the phtocatalytic activity of Zinc Sulphide.
\end{abstract}

Keywords: Doping; Photocatalyst; Photoluminescence; Pollution; Sol-gel synthesis; Zinc sulphide nanoparticles

\section{Introduction}

Resorcinol is one of the pollutants in the effluent of chemical, fertilizer and dye industries and is a typical constituent of coal conversion wastewater. It is released into the environment during production and processing that can cause environmental pollution. It will also be released directly during uses and disposal of resorcinol containing consumer and professional products like hair dye. It is the main content of hair dyes and all non-reacted Resorcinol is rinsed off to the wastewater after the 30-min period of typical use [1].

Resorcinol has many adverse effects on the body of human being. It may cause skin irritation on contact with skin. Inhalation may affect lung or trachea damage and allergic reaction in respiratory track [1]. Also it is listed as an endocrine disruptor [2].

Typical waste water treatments cannot remove the resorcinol and other phenolic compounds completely. Advance Oxidation Process such as (1) $\mathrm{O}_{3} / \mathrm{H}_{2} \mathrm{O}_{2}$ (2) $\mathrm{O}_{3} / \mathrm{Fe}^{2+}$ (3) $\mathrm{UV} / \mathrm{O}_{3} / \mathrm{H}_{2} \mathrm{O}_{2}$ (4) $\mathrm{O}_{3} / \mathrm{H}_{2} \mathrm{O}_{2} / \mathrm{Fe}^{2+}$ have been extensively used. Also the $\mathrm{H}_{2} \mathrm{O}_{2} / \mathrm{UV}, \mathrm{Fe}^{2+} / \mathrm{H}_{2} \mathrm{O}_{2} / \mathrm{UV}$ and $\mathrm{TiO}_{2} / \mathrm{UV}, \mathrm{TiO}_{2} / \mathrm{H}_{2} \mathrm{O}_{2} / \mathrm{UV}$ photocatalytic processes have been used for the same purpose [3]. But it has more requirements of capital intensive and have some limitations.

In recent years, a cost effective new trend is developed for the complete removal of organic pollutants called photocatalysis. The photocatalysis involves use of semiconductor catalyst which is being active in presence of light for the production of $\mathrm{OH}$ radicals. When light of energy greater than band gap energy fall on the surface of the photocatalyst, there occurs formation of electron $\left(\mathrm{e}^{-}\right)$and hole $\left(\mathrm{h}^{+}\right)$. The hole has extensive reduction potential that produces $\mathrm{OH}$ radicals [4]. The produced $\mathrm{OH}$ radicals have highest oxidation potential that can degrade whole organic compound to Carbon dioxide and water
$[5,6]$. Most extensively used semiconductors are $\mathrm{TiO}_{2}, \mathrm{ZnO}, \mathrm{CdS}, \mathrm{WO}_{3}$, $\mathrm{ZnS}$ and $\mathrm{SnO}_{2}$ [7].

Amongst the above mentioned photocatalyst Zinc Suphide $(\mathrm{ZnS})$ is an important II-VI wide band-gap semiconductor having excellent physical properties, like size-dependent electrical and optical properties, due to the quantum confinement [8]. It exists in two main crystalline forms. One is the cubic zinc blende (sphalerite) and the other is the hexagonal wurtzite. Both are crystalline forms having band gaps of $3.54 \mathrm{eV}$ and $3.77 \mathrm{eV}$ belong to cubic zinc blende and hexagonal wurtzite ZnS respectively [4]. Cubic Zinc blende structure of Zinc Sulphide is more stable than the hexagonal structure. Very few work was noticed in the field of photocatalytic activity of metal co-doped Zinc Sulphide. Earliar researchers have studied the effect of metal and non metal doping on the Zinc Sulphide nanoparticles thereby successful decrease in band gap but shows $50-80 \%$ degradation efficiency [7]. In this attempt co-doping of the metals have been studied with doping of Tin and Strontium. The incorporation of Sn and $\mathrm{Sr}$ decreases the band gap and increases the photocatalytic activity of Zinc Sulphide with complete degradation of resorcinol.

Photocatalytic semiconducting materials have been prepared by various methods like Chemical co-precipitation, Chemical bath deposition, Hydrothermal, Sol-Gel, microwave, Successive Ionic Layer Adsorption and Reaction, Mechano-chemical method etc. [8-11]. In present study Zinc Sulphide nanoparticles were prepared by Sol-Gel method. It involves conversion of monomers into a colloidal solution i.e., sol which on heating converts to gel (an integrated network). Gel on calcination forms fine nanosized particles. This is very effective and widely used method for semiconductor synthesis.

\section{Materials and Methods}

Chemicals used for the preparation of Zinc Sulphide nanoparticles were of analytical grade reagents. It were used without further 
Citation: Bhagat MM, Lokhande P, Mujawar HA (2018) Effect of Tin and Strontium Doping on the Photocatalytic Activity of Zinc Sulphide Nanoparticles for the Photocatalytic Degradation of Resorcinol under Solar and Ultra-Violet Light. J Nanosci Curr Res 3: 122. doi: $10.4172 / 2572-0813.1000122$

Page 2 of 7

purification. For the preparation of Pure Zinc Sulphide, Zinc Acetate dihydrate $\mathrm{Zn}\left(\mathrm{CH}_{3} \mathrm{COO}\right)_{2} \cdot 2 \mathrm{H}_{2} \mathrm{O}$ and Thiourea $\left(\mathrm{CS}\left(\mathrm{NH}_{2}\right)_{2}\right)$ were taken in a molar proportion $(0.1 \mathrm{M})$. For the doping of metals Strontium and Tin, Strontium Nitrate $\mathrm{Sr}\left(\mathrm{NO}_{3}\right)_{2}$ and Stannous Chloride $\mathrm{SnCl} 2.2 \mathrm{H} 2 \mathrm{O}$ were taken respectively. Four samples of different proportions A$\left(\mathrm{Sn}_{0.02}, \mathrm{Sr}_{0.08}: \mathrm{ZnS}\right), \mathrm{B}-\left(\mathrm{Sn}_{0.04}, \mathrm{Sr}_{0.06}: \mathrm{ZnS}\right), \mathrm{C}-\left(\mathrm{Sn}_{0.06}, \mathrm{Sr}_{0.04}: \mathrm{ZnS}\right)$ and $\mathrm{D}-\left(\mathrm{Sn}_{0.08}, \mathrm{Sr}_{0.02}: \mathrm{ZnS}\right)$ were prepared. These samples were prepared by applying the molar proportion formula $\operatorname{Snx} \operatorname{Sry} \mathrm{Zn}_{\mathrm{x}(1-\mathrm{x}+\mathrm{y})} \mathrm{S}$.

For the preparation of doped Zinc Sulphide, appropriate weights of required chemicals were dissolved in $100 \mathrm{ml}$ methanol. Firstly Solutions of Zinc Acetate, Strontium Nitrate and Stannous Chloride were mixed and stirred on the magnetic stirrer for 10 minutes. Then Thiourea solution was added drop wise for proper nucleation. $25 \mathrm{ml}$ ethylene glycol was also added as a capping agent. The temperature was raised to $80^{\circ} \mathrm{C}$. This mixture was continuously stirred for 6 hours. Initially colourless sol is formed which was then turned to pink colour gel. This gel was dried on magnetic stirrer and calcined at $750^{\circ} \mathrm{C}$ in muffle Furnace for an hour. After Calcination product were collected and taken for characterisation. Same procedure was repeated for the synthesis of pure zinc sulphide by using Zinc Acetate and Thiourea.

The samples were characterised by TG-DTA, XRD, SEM-EDX and UV-Visible spectroscopy. Photocatalytic activity of the doped and undoped photocatalyst were studied by degrading $100 \mathrm{ml}$ of $20 \mathrm{ppm}$ Resorcinol solution in visible light as well as in UV light.

\section{Results and Discussion}

\section{Characterisation}

In the Characterisation of samples, Morphology was studied by Scanning Electron Microscopy (SEM), Crystal structure by X-Ray Diffraction (XRD), Calcination temperature Thermal Gravimetric Differential Thermal Analysis (TG-DTA), Optical Study by UV-Visible Spectroscopy and photoluminescence Spectroscopy.

\section{TGA analysis}

Thermal properties of ZnS prepared by Sol-Gel method were studied with the TG-DTA. The TGA-DTA graph for prepared Zinc Sulphide nanoparticles is shown in Figure 1.

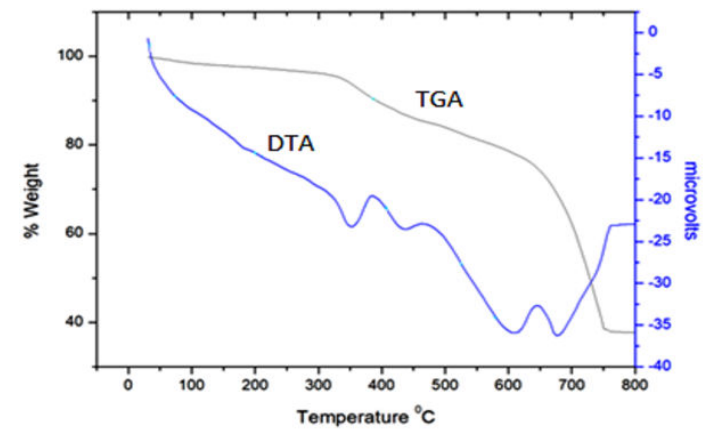

Figure 1: TGA-DTA graph for prepared zinc sulphide nanoparticles.

The thermal stability of the nanocomposites was found at $750^{\circ} \mathrm{C}$. Up to this temperature structural changes take place. No change in weight of $\mathrm{ZnS}$ was found after $750^{\circ} \mathrm{C}$. So the all samples of doped Zinc Sulphide were calcined on $750^{\circ} \mathrm{C}$ temperature.

\section{Scanning electron microscopy (SEM)}

Morphological study of pure and Sr and Sn doped Zinc Sulphide prepared by Sol-Gel method was carried out by Scanning Electron Microscopy. Figure 2 shows the SEM images for A- $\left(\mathrm{Sn}_{0.02}, \mathrm{Sr}_{0.08}: \mathrm{ZnS}\right)$, B-(Sn0.04, $\left.\mathrm{Sr}_{0.06}: \mathrm{ZnS}\right), \mathrm{C}-\left(\mathrm{Sn}_{0.06}, \mathrm{Sr}_{0.04}: \mathrm{ZnS}\right), \mathrm{D}-\left(\mathrm{Sn}_{0.08}, \mathrm{Sr}_{0.02}: \mathrm{ZnS}\right)$ and E-Pure $\mathrm{ZnS}$ respectively.

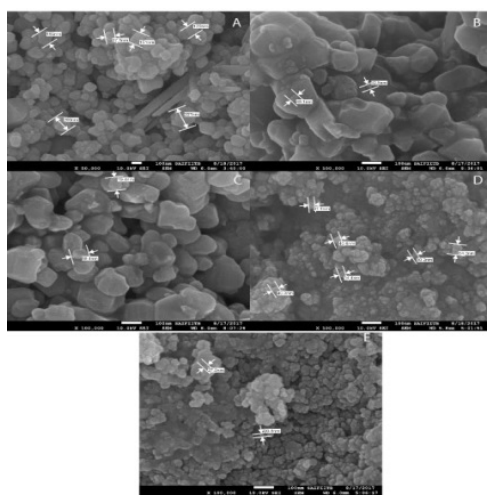

Figure 2: SEM images of A- $\left(\mathrm{Sn}_{0.02}, \mathrm{Sr}_{0.08}: \mathrm{ZnS}\right), \mathrm{B}-\left(\mathrm{Sn}_{0.04}, \mathrm{Sr}_{0.06}\right.$ : $\mathrm{ZnS}), \mathrm{C}-\left(\mathrm{Sn}_{0.06}, \mathrm{Sr}_{0.04}: \mathrm{ZnS}\right), \mathrm{D}-\left(\mathrm{Sn}_{0.08}, \mathrm{Sr}_{0.02}: \mathrm{ZnS}\right)$ and E-Pure $\mathrm{ZnS}$ respectively.

The SEM images for each sample gives the idea of the spherical shape crystals of pure and Sr and Sn doped zinc sulphide. Crystals appears mostly hexagonal shape which was further confirmed by XRD.

\section{Energy dispersive X-ray spectroscopy (EDX)}

Elemental analysis of prepared pure and doped Zinc Sulphide executed by Energy Dispersive X-Ray Speectroscopy. Figure 3 shows the EDX images of $\left(\mathrm{Sn}_{0.02}, \mathrm{Sr}_{0.08}: \mathrm{ZnS}\right),\left(\mathrm{Sn}_{0.04}, \mathrm{Sr}_{0.06}: \mathrm{ZnS}\right),\left(\mathrm{Sn}_{0.06}\right.$, $\left.\mathrm{Sr}_{0.04}: \mathrm{ZnS}\right),\left(\mathrm{Sn}_{0.08}, \mathrm{Sr}_{0.02}: \mathrm{ZnS}\right)$ and Pure $\mathrm{ZnS}$ respectively.

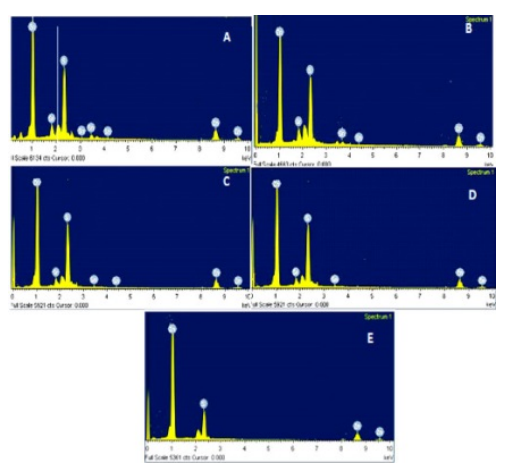

Figure 3: $\mathrm{EDX}$ images of $\mathrm{A}-\left(\mathrm{Sn}_{0.02}, \mathrm{Sr}_{0.08}: \mathrm{ZnS}\right), \mathrm{B}-\left(\mathrm{Sn}_{0.04}, \mathrm{Sr}_{0.06}\right.$ : $\mathrm{ZnS}), \mathrm{C}-\left(\mathrm{Sn}_{0.06}, \mathrm{Sr}_{0.04}: \mathrm{ZnS}\right), \mathrm{D}-\left(\mathrm{Sn}_{0.08}, \mathrm{Sr}_{0.02}: \mathrm{ZnS}\right)$ and E-Pure $\mathrm{ZnS}$ respectively.

The EDX images 3A, 3B, 3C and 3D shows the presence of Sr and Sn peaks indicating the successful assimilation of these elements in the 
Citation: Bhagat MM, Lokhande P, Mujawar HA (2018) Effect of Tin and Strontium Doping on the Photocatalytic Activity of Zinc Sulphide Nanoparticles for the Photocatalytic Degradation of Resorcinol under Solar and Ultra-Violet Light. J Nanosci Curr Res 3: 122. doi: $10.4172 / 2572-0813.1000122$

Page 3 of 7

crystal of Zinc Sulphide. Image 5E is the EDX image of pure Zinc sulphide showing the abundant peak for Zinc and Sulphur. The above EDX images reveal the successful doping of Tin and Strontium in the crystals lattice of Zinc sulphide.

\section{$\mathrm{X}$-ray diffraction analysis $(\mathrm{XRD})$}

Crystal structure of the pure and doped Zinc Sulphide was confirmed by means of planes of Zinc Sulphide determined by the XRD analysis. Particle size of prepared Zinc Sulphide by Sol-Gel method was calculated from XRD data. Figure 4 is the XRD ghraph for Samples A, B, C, D and E respectively.

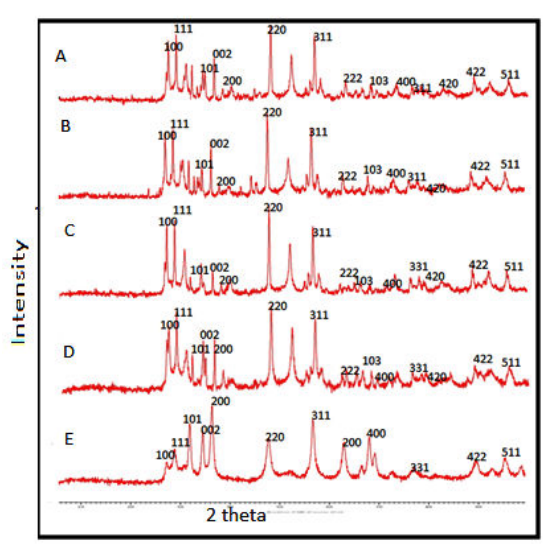

Figure 4: XRD graph for $\mathrm{A}-\left(\mathrm{Sn}_{0.02}, \mathrm{Sr}_{0.08}: \mathrm{ZnS}\right), \mathrm{B}-\left(\mathrm{Sn}_{0.04}, \mathrm{Sr}_{0.06}\right.$ : $\mathrm{ZnS}), \mathrm{C}-\left(\mathrm{Sn}_{0.06}, \mathrm{Sr}_{0.04}: \mathrm{ZnS}\right), \mathrm{D}-\left(\mathrm{Sn}_{0.08}, \mathrm{Sr}_{0.02}: \mathrm{ZnS}\right)$ and E-Pure $\mathrm{ZnS}$ respectively.

The XRD planes present in graph E viz. 100, 111, 101, 002, 200, 220, $311,400,331,422$ and 511 are the planes that belongs to $2 \theta$ values $27.19^{\circ}, 28.84^{\circ}, 31.87^{\circ}, 34.41^{\circ}, 36.39^{\circ}, 52.09^{\circ}, 56.67^{\circ}, 62.97^{\circ}, 69.13^{\circ}, 77^{\circ}$, $95.17^{\circ}$ respectively representing the Wurtzite (Hexagonal) structure of Zinc Sulphide which are perfectly matches with JCPDS Card No. 39-1363. Beside this, graph A, B, C, D shows additional planes 103 , 420, 222 which are present because of Sr and Sn doping. 420 is for Sn and 103 and 222 are the planes for Sr impurity.

The particle size of pure and Sr and Sn doped Zinc Sulphide was calculated for each sample of Zinc Sulphide by using Sherrer Equation:

\section{$\mathrm{d}=\mathrm{n} \lambda / \beta \cos \theta$}

For the Sn and Sr doped samples A, B, C and D 220 plane has chosen for the calculation of particle size because it have relative intensity $100 \%$, belonging to $2 \theta$ values $47.71^{\circ}, 47.64^{\circ}, 47.69^{\circ}, 47.70^{\circ}$ respectively. Plane 200 is used for pure Zinc Sulphide corresponded to $36.39^{\circ}$.

Particle size of each sample of Zinc sulphide (doped and undoped) is listed as in Table 1.

\begin{tabular}{|l|l|l|}
\hline S.No & Sample & Particle Size $\mathbf{n m}$ \\
\hline 1 & $\mathrm{Sn}_{0.02}, \mathrm{Sr}_{0.08}: \mathrm{ZnS}$ & 90.2 \\
\hline 2 & $\mathrm{Sn}_{0.04}, \mathrm{Sr}_{0.06}: \mathrm{ZnS}$ & 135 \\
\hline 3 & $\mathrm{Sn}_{0.06}, \mathrm{Sr}_{0.04}: \mathrm{ZnS}$ & 90.35 \\
\hline
\end{tabular}

\begin{tabular}{|l|l|l|}
\hline 4 & $\mathrm{Sn}_{0.08}, \mathrm{Sr}_{0.02}: \mathrm{ZnS}$ & 77.3 \\
\hline 5 & Pure $\mathrm{ZnS}$ & 135.6 \\
\hline
\end{tabular}

Table 1: Particle size for for A- $\left(\mathrm{Sn}_{0.02}, \mathrm{Sr}_{0.08}: \mathrm{ZnS}\right), \mathrm{B}-\left(\mathrm{Sn}_{0.04}, \mathrm{Sr}_{0.06}\right.$ : $\mathrm{ZnS}), \mathrm{C}-\left(\mathrm{Sn}_{0.06}, \mathrm{Sr}_{0.04}: \mathrm{ZnS}\right), \mathrm{D}-\left(\mathrm{Sn}_{0.08}, \mathrm{Sr}_{0.02}: \mathrm{ZnS}\right)$ and E-Pure ZnS.

From the Table 1 Sample D $\mathrm{Sn}_{0.08}, \mathrm{Sr}_{0.02}$ : $\mathrm{ZnS}$ have smallest particle size $77.3 \mathrm{~nm}$ amongst the rest of the Sr and Sn doped and pure Zinc Sulphide samples prepared by Sol-Gel method.

$\mathrm{B}-\mathrm{Sn}_{0.04}, \mathrm{Sr}_{0.06}: \mathrm{ZnS}$ and pure Zinc Sulphide have the particle size $135 \mathrm{~nm}$ that may show the lowest photocatalytic activity than the other

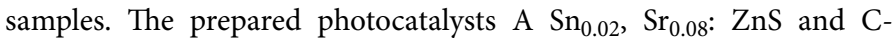
$\mathrm{Sn}_{0.06}, \mathrm{Sr}_{0.04}: \mathrm{ZnS}$ have the particle size $90.2 \mathrm{~nm}$ and $90.35 \mathrm{~nm}$ respectively calculated by Sherrer formula.

\section{UV-Visible spectroscopy}

UV-Visible spectroscopic analysis is used for the calculation of band gap by measuring wavelength maximum for each sample. The wavelength maximum of prepared pure and doped zinc sulphide was checked on the Equiptronics EQ 820 UV-Visible spectrophotometer. From the $\lambda$ max data, band gap was calculated by using the formula,

Band Gap Energy $(E)=h{ }^{\star} \mathrm{C} / \lambda$

Where,

$$
\begin{aligned}
& \mathrm{h}=\text { Planks constant } \\
& \mathrm{C}=\text { Speed of light } \\
& \lambda=\text { Cut off wavelength }
\end{aligned}
$$

The Figure 5 is showing the UV-Visible spectra of doped and undoped Zinc Sulphide nanoparticles. Band gap energies for Sn and Sn doped Zinc Sulphide and Pure Zinc Sulphide are given in Table 2.

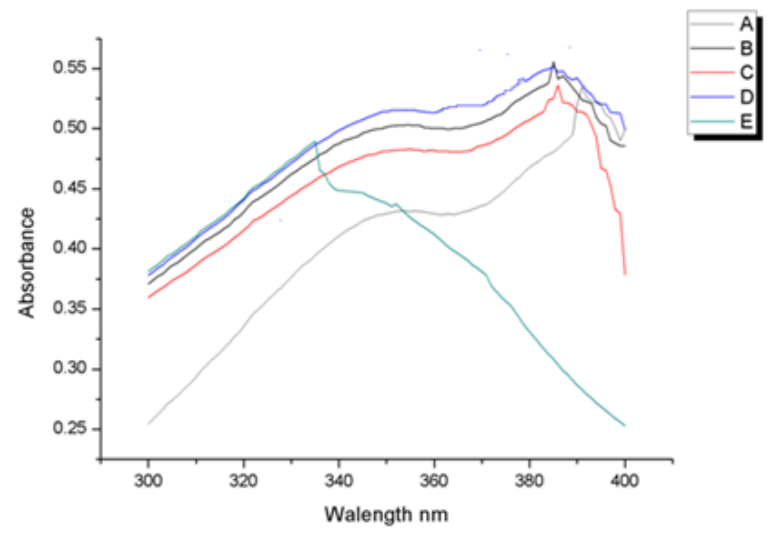

Figure 5: UV-Visible spectra for A- $\left(\mathrm{Sn}_{0.02}, \mathrm{Sr}_{0.08}: \mathrm{ZnS}\right), \mathrm{B}-\left(\mathrm{Sn}_{0.04}\right.$, $\left.\mathrm{Sr}_{0.06}: \mathrm{ZnS}\right), \mathrm{C}-\left(\mathrm{Sn}_{0.06}, \mathrm{Sr}_{0.04}: \mathrm{ZnS}\right), \mathrm{D}-\left(\mathrm{Sn}_{0.08}, \mathrm{Sr}_{0.02}: \mathrm{ZnS}\right)$ and $\mathrm{E}-$ Pure $\mathrm{ZnS}$ respectively.

\begin{tabular}{|l|l|l|l|}
\hline S.No & Samples & Wavelengh Amax & Band Gap eV \\
\hline 1 & $\mathrm{Sn}_{0.02} \mathrm{Sr}_{0.08} \mathrm{ZnS}$ & $391 \mathrm{~nm}$ & 3.1 \\
\hline 2 & $\mathrm{Sn}_{0.04} \mathrm{Sr}_{0.06} \mathrm{ZnS}$ & $385 \mathrm{~nm}$ & 3.22 \\
\hline
\end{tabular}


Citation: Bhagat MM, Lokhande P, Mujawar HA (2018) Effect of Tin and Strontium Doping on the Photocatalytic Activity of Zinc Sulphide Nanoparticles for the Photocatalytic Degradation of Resorcinol under Solar and Ultra-Violet Light. J Nanosci Curr Res 3: 122. doi: $10.4172 / 2572-0813.1000122$

Page 4 of 7

\begin{tabular}{|l|l|l|l|}
\hline 3 & $\mathrm{Sn}_{0.06} \mathrm{Sr}_{0.04} Z \mathrm{nS}$ & $386 \mathrm{~nm}$ & 3.21 \\
\hline 4 & $\mathrm{Sn}_{0.08} \mathrm{Sr}_{0.02} Z \mathrm{nS}$ & $385 \mathrm{~nm}$ & 3.22 \\
\hline 5 & Pure ZnS & $335 \mathrm{~nm}$ & 3.7 \\
\hline
\end{tabular}

wavelength on doping with Tin and Strontium. For sample A $\left(\mathrm{Sn}_{0.02}\right.$, $\left.\mathrm{Sr}_{0.08}: \mathrm{ZnS}\right)$ it was at $363 \mathrm{~nm}$ and for $\mathrm{B}-\left(\mathrm{SnO}_{.04}, \mathrm{Sr}_{0.06}: \mathrm{ZnS}\right)$ it was located at $353 \mathrm{~nm}$. While for photocatalysts C- $\left(\mathrm{Sn}_{0.06}, \mathrm{Sr}_{0.04}: \mathrm{ZnS}\right)$ and $\mathrm{D}$ - $\left(\mathrm{Sn}_{0.08}, \mathrm{Sr}_{0.02}: \mathrm{ZnS}\right)$ the emission peak was at $350 \mathrm{~nm}$. In summary on doping with the Tin and Strontium to the Zinc Sulphide the emission band shifted towards the blue shift. This blue shift of $\mathrm{ZnS}$ on

Table 2: Band gap energies of strontium and tin doped and undoped zinc sulphide nanoparticles.

Band gap of Pure Zinc Sulphide prepared by Sol-Gel method was found to $3.70 \mathrm{eV}$ that exactly the band gap of hexagonal Zinc Sulphide. This band was then decreased for all the samples. For sample it was 3.1 $\mathrm{eV}$ as there was higher concentration of Strontium and it remained almost constant for sample B, C and D. It was found to be $3.2 \mathrm{eV}$.

\section{Photoluminescence spectroscopy}

The photoluminescence spectra of all the five samples with the excitation wavelength of $300 \mathrm{~nm}$ shows the emission peak for Sn and Sr doped zinc sulphide and pure Zinc sulphide as shown in Figure 6.

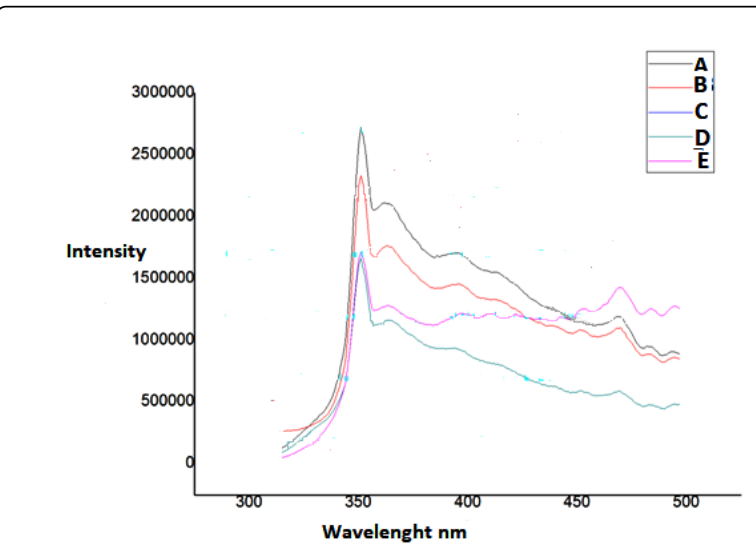

Figure 6: Photoluminescence spectra for $\mathrm{A}-\left(\mathrm{Sn}_{0.02}, \mathrm{Sr}_{0.08}: \mathrm{ZnS}\right)$, B$\left(\mathrm{Sn}_{0.04}, \mathrm{Sr}_{0.06}: \mathrm{ZnS}\right), \mathrm{C}-\left(\mathrm{Sn}_{0.06}, \mathrm{Sr}_{0.04}: \mathrm{ZnS}\right), \mathrm{D}-\left(\mathrm{Sn}_{0.08}, \mathrm{Sr}_{0.02}: \mathrm{ZnS}\right)$ and $\mathrm{E}-\mathrm{Pure} \mathrm{ZnS}$ respectively.

The pure Zinc Sulphide prepared by Sol-Gel method (E) has shown broad emission peak at $469 \mathrm{~nm}$ which was shifted to the shorter doping with the $\mathrm{Sn}$ and $\mathrm{Sr}$ is due to the higher crystallinity of doped ZnS than the pure ZnS [12-14].

\section{Photocatalytic degradation experiments}

Photocatalytic reaction experiments were carried out in solar light and in an UV light. For both light source reaction, the $100 \mathrm{ml}$ of resorcinol solution was loaded with $100 \mathrm{mg}$ of pure and $\mathrm{Sr}$ and Sn doped zinc sulphide photocatalyst.

\section{Photocatalytic degradation experiment in UV light}

For the UV light photocatalytic degradation experiment, special UV-light chamber called UV-photoreactor was used. In the reaction vessel of UV photoreactor $100 \mathrm{ml}$ of $20 \mathrm{ppm}$ Resorcinol solution was stirred with $100 \mathrm{mg}$ of photocatalyst. The temperature of the reaction vessel was maintained below $25^{\circ} \mathrm{C}$ to avoid decomposition of Resorcinol by thermal decomposition. The light source used was 13 watt UV lamp that produces 4210 lux intense light which was measured by lux meter. Photocatalytic degradation reaction experiments were executed for each sample of Sr and Sn doped Zinc Sulphide and pure Zinc Sulphide for about 90 minutes. The samples were collected for the determination of COD at 15 minutes time interval.

The calculated COD of 20 ppm Resorcinol was found to be 320 ppm. From Table 3 it is observed that pure Zinc Sulphide prepared by sol-gel method Showed $90 \%$ degradation of Resorcinol. But the sample A $\mathrm{Sn}_{0.02} \mathrm{Sr}_{0.08} \mathrm{ZnS}, \mathrm{C} \mathrm{Sn} \mathrm{Sn}_{0.06} \mathrm{Sr}_{0.04} \mathrm{ZnS}$ and $\mathrm{D} \mathrm{Sn} \mathrm{S}_{0.08} \mathrm{Sr}_{0.02} \mathrm{ZnS}$ showed the complete degradation of Resorcinol. Among these three catalysts, D $\mathrm{Sn}_{0.08} \mathrm{Sr}_{0.02} \mathrm{ZnS}$ catalyst is the fastest catalyst for the degradation of Resorcinol. This is because the particle size of these catalysts is smaller than pure Zinc Sulphide that provided large surface area for the photocatalytic reaction.

\begin{tabular}{|c|c|c|c|c|c|}
\hline Time in minutes & $\begin{array}{l}\text { COD for Pure } \\
\text { ZnS }\end{array}$ & COD for $\mathrm{Sn}_{0.02} \mathrm{Sr}_{0.08} \mathrm{ZnS}$ & COD for $\mathrm{Sn}_{0.04} \mathrm{Sr}_{0.06} \mathrm{ZnS}$ & COD for $\mathbf{S n}_{0.06} \mathbf{S r}_{0.04} \mathrm{ZnS}$ & $\operatorname{COD}$ for $\mathrm{Sn}_{0.08} \mathrm{Sr}_{0.02} \mathrm{ZnS}$ \\
\hline 15 & 88 & 120 & 88 & 160 & 80 \\
\hline 30 & 72 & 96 & 80 & 144 & 40 \\
\hline 45 & 56 & 48 & 80 & 24 & 8 \\
\hline 60 & 56 & 32 & 40 & 24 & 0 \\
\hline 75 & 32 & 0 & 40 & 0 & 0 \\
\hline 90 & 32 & 0 & 40 & 0 & 0 \\
\hline
\end{tabular}

Table 3: COD for A- $\left(\mathrm{Sn}_{0.02}, \mathrm{Sr}_{0.08}: \mathrm{ZnS}\right), \mathrm{B}-\left(\mathrm{Sn}_{0.04}, \mathrm{Sr}_{0.06}: \mathrm{ZnS}\right)$, C-(Sn0 $\left.{ }_{.06}, \mathrm{Sr}_{0.04}: \mathrm{ZnS}\right), \mathrm{D}-\left(\mathrm{Sn}_{0.08}, \mathrm{Sr}_{0.02}: \mathrm{ZnS}\right)$ and E-Pure ZnS respectively in UV light. 
Citation: Bhagat MM, Lokhande P, Mujawar HA (2018) Effect of Tin and Strontium Doping on the Photocatalytic Activity of Zinc Sulphide Nanoparticles for the Photocatalytic Degradation of Resorcinol under Solar and Ultra-Violet Light. J Nanosci Curr Res 3: 122. doi: $10.4172 / 2572-0813.1000122$

Page 5 of 7

\section{Photocatalytic degradation in solar light}

For the solar light Photodegradation by prepared pure and Strontium and Tin doped Zinc Sulphide, $100 \mathrm{ml}$ Resorcinol solution loaded with $100 \mathrm{mg}$ of photocatalyst was stirred for six hours under sun light. The samples were collected at each for the determination COD for each hour. The calculated COD for $20 \mathrm{ppm}$ Resorcinol was $320 \mathrm{ppm}$ as mentioned above.
It was observed from Table 4 that amongst all the photocatalysts prepared by sol-gel method, $\mathrm{Sn}_{0.08} \mathrm{Sr}_{0.02} \mathrm{ZnS}$ shown highest and complete degradation of Resorcinol after six hour Photodegradation. $\mathrm{Sn}_{0.08} \mathrm{Sr}_{0.02} \mathrm{ZnS}$ photocatalyst has lowest particle size $77.3 \mathrm{~nm}$ than the rest of the photocatalysts that provides wide surface for the photocatalytic reaction.

\begin{tabular}{|c|c|c|c|c|c|}
\hline Time in hour & $\begin{array}{l}\text { COD for Pure } \\
\text { ZnS }\end{array}$ & COD for $\mathbf{S n}_{0.02} \mathbf{S r}_{0.08} \mathrm{ZnS}$ & COD for $\mathbf{S n}_{0.04} \mathbf{S r}_{0.06} \mathrm{ZnS}$ & COD for $\mathbf{S n}_{0.06} \mathbf{S r}_{0.04} \mathrm{ZnS}$ & COD for $\mathrm{Sn}_{0.08} \mathrm{Sr}_{0.02} \mathrm{ZnS}$ \\
\hline 1 & 120 & 40 & 120 & 120 & 88 \\
\hline 2 & 112 & 40 & 104 & 80 & 72 \\
\hline 3 & 112 & 40 & 80 & 80 & 40 \\
\hline 4 & 96 & 40 & 65 & 80 & 40 \\
\hline 5 & 80 & 32 & 40 & 48 & 24 \\
\hline 6 & 64 & 32 & 40 & 38 & 0 \\
\hline
\end{tabular}

Table 4: COD for for A-( $\mathrm{Sn}_{0.02}, \mathrm{Sr}_{0.08}$ : $\left.\mathrm{ZnS}\right), \mathrm{B}-\left(\mathrm{Sn}_{0.04}, \mathrm{Sr}_{0.06}: \mathrm{ZnS}\right), \mathrm{C}-\left(\mathrm{Sn}_{0.06}, \mathrm{Sr}_{0.04}: \mathrm{ZnS}\right), \mathrm{D}-\left(\mathrm{Sn}_{0.08}, \mathrm{Sr}_{0.02}: \mathrm{ZnS}\right)$ and E-Pure $\mathrm{ZnS}$ respectively for solar light photodegradation Resorcinol.

\section{Effect of catalyst loading}

Catalyst dosage is extrinsic parameter that directly affects the photocatalytic activity of photocatalyst. The effect of dosage of photocatalyst was studied by loading the each samples i.e., for A$\left(\mathrm{Sn}_{0.02}, \mathrm{Sr}_{0.08}: \mathrm{ZnS}\right), \mathrm{B}-\left(\mathrm{Sn}_{0.04}, \mathrm{Sr}_{0.06}: \mathrm{ZnS}\right), \mathrm{C}-\left(\mathrm{Sn}_{0.06}, \mathrm{Sr}_{0.04}: \mathrm{ZnS}\right)$, D$\left(\mathrm{Sn}_{0.08}, \mathrm{Sr}_{0.02}: \mathrm{ZnS}\right)$ and E-Pure ZnS samples. $50 \mathrm{mg}, 100 \mathrm{mg}, 150 \mathrm{mg}$ and $200 \mathrm{mg}$ of each photocatalyst sample was mixed with $100 \mathrm{ml}$ of 20 ppm Resorcinol solution and stirred for 6 hours under Solar light. The samples were irradiated with sunlight with constant stirring for about six hours. Figure 7 showing the graphs for effect of catalyst loading for Sample A, B, C, D and E samples for Sn and Sr doped Zinc Sulphide and Pure Zinc Sulphide.

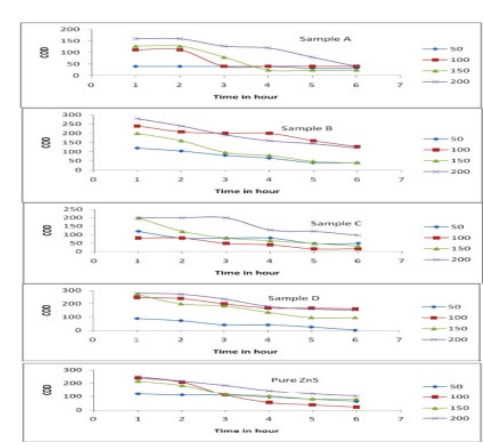

Figure 7: Effect of catalyst loading for $\mathrm{A}-\left(\mathrm{Sn}_{0.02}, \mathrm{Sr}_{0.08}: \mathrm{ZnS}\right), \mathrm{B}-$ $\left(\mathrm{Sn}_{0.04}, \mathrm{Sr}_{0.06}: \mathrm{ZnS}\right), \mathrm{C}-\left(\mathrm{Sn}_{0.06}, \mathrm{Sr}_{0.04}: \mathrm{ZnS}\right), \mathrm{D}-\left(\mathrm{Sn}_{0.08}, \mathrm{Sr}_{0.02}: \mathrm{ZnS}\right)$ and E-Pure $\mathrm{ZnS}$ respectively.

For all the doped and undoped Zinc Sulphide nanoparticles prepared by sol-gel method $50 \mathrm{mg}$ and $100 \mathrm{mg}$ catalysts shown the highest photocatalytic activity than the rest $150 \mathrm{mg}$ and $200 \mathrm{mg}$ catalyst concentration. As the catalyst concentration increases less light radiation falls on the surface of the photocatalyst because of rush of catalyst particles. Optimum catalysts concentration for the Zinc Sulphide is $50 \mathrm{mg} / 100 \mathrm{ml}$ Resorcinol that shown clearly highest degradation rate for $\mathrm{A}-\left(\mathrm{Sn}_{0.02}, \mathrm{Sr}_{0.08}: \mathrm{ZnS}\right), \mathrm{B}-\left(\mathrm{Sn}_{0.04}, \mathrm{Sr}_{0.06}: \mathrm{ZnS}\right)$, , D$\left(\mathrm{Sn}_{0.08}, \mathrm{Sr}_{0.02}: \mathrm{ZnS}\right)$ and for C-(Sn0.06, $\left.\mathrm{Sr}_{0.04}: \mathrm{ZnS}\right)$ E-Pure $\mathrm{ZnS}$ both $100 \mathrm{mg}$ and $50 \mathrm{mg}$ shown similar degradation rate.

\section{pH effect}

$\mathrm{pH}$ is an extrinsic parameter that affects the phtocatalytic activity of the photocatalyst. This study was done by performing the degradation of $20 \mathrm{ppm}$ resorcinol $(100 \mathrm{ml})$ dosed with $50 \mathrm{mg}$ of photocatalyst in presence of UV light. The proportion of catalysts and resorcinol solution was kept same for all doped and undoped zinc sulphide nanoparticles samples. The reaction was carried out for 90 minutes. The samples were taken out for the determination of COD at 15 minutes time interval. The graph of $\mathrm{pH}$ effect for samples $\mathrm{A}, \mathrm{B}, \mathrm{C}, \mathrm{D}$ and $\mathrm{E}$ is illustrated in Figure 8. 
Citation: Bhagat MM, Lokhande P, Mujawar HA (2018) Effect of Tin and Strontium Doping on the Photocatalytic Activity of Zinc Sulphide Nanoparticles for the Photocatalytic Degradation of Resorcinol under Solar and Ultra-Violet Light. J Nanosci Curr Res 3: 122. doi: $10.4172 / 2572-0813.1000122$

Page 6 of 7

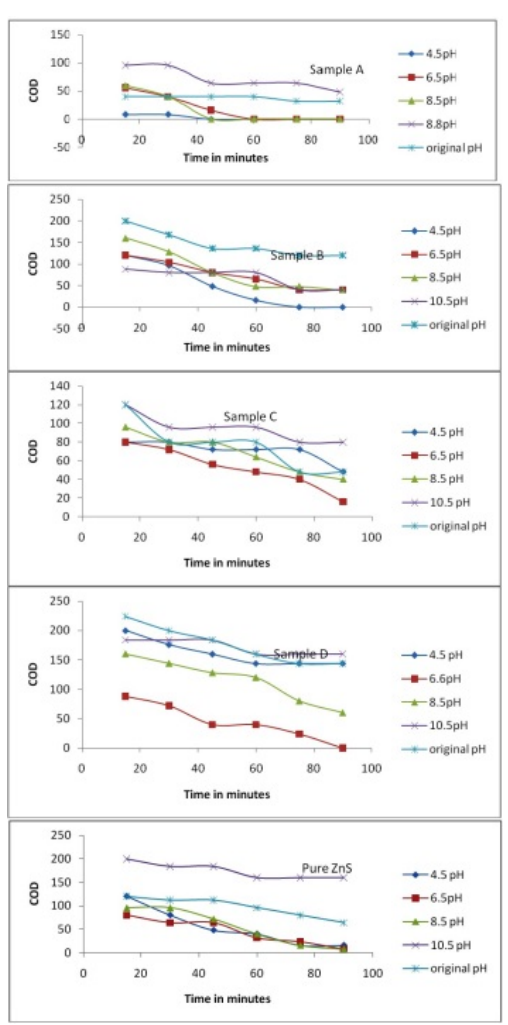

Figure 8: $\mathrm{pH}$ effect for A-( $\left.\mathrm{Sn}_{0.02}, \mathrm{Sr}_{0.08}: \mathrm{ZnS}\right), \mathrm{B}-\left(\mathrm{Sn}_{0.04}, \mathrm{Sr}_{0.06}: \mathrm{ZnS}\right)$, $\mathrm{C}-\left(\mathrm{Sn}_{0.06}, \mathrm{Sr}_{0.04}: \mathrm{ZnS}\right), \mathrm{D}-\left(\mathrm{Sn}_{0.08}, \mathrm{Sr}_{0.02}: \mathrm{ZnS}\right)$ and E-pure $\mathrm{ZnS}$ respectively.

The photocatalyst surface is positively charged in acidic solutions and negatively charged in alkaline solutions [15-18]. Since resorcinol is weakly acidic in nature that shows degradation at near about neutral $\mathrm{pH}$.

The actual $\mathrm{pH}$ of the resorcinol and catalyst suspension was noted $5.8 \mathrm{pH}$. At this $\mathrm{pH}$ surface of the catalyst have zero point charge [8]. Above this $\mathrm{pH}$ surface charge become negatively charged hence more adsorption of resorcinol on the surface of the catalyst promoting the degradation at higher $\mathrm{pH}$ than the original one.

The prepared catalysts $\mathrm{Sr}$ and $\mathrm{Sn}$ doped $\mathrm{ZnS}$ and Pure $\mathrm{ZnS}$ shows more degradation at $\mathrm{pH}$ 6.5. The $\mathrm{pH} 6.5$ is the optimum $\mathrm{pH}$ for strontium and tin doped zinc sulphide photocatalyst.

\section{Reutilisation of photocatalyst}

Reutilisation of above Sr and Sn doped Zinc Sulphide and pure Zinc Sulphide prepared by Sol-Gel method was checked by collecting the photocatalyst after use. The collected photocatalyst was washed with water several times and completely dried in an oven. These dried catalysts were loaded with $50 \mathrm{mg} / 50 \mathrm{ml}$ of $20 \mathrm{ppm}$ Resorcinol solution. The photocatalytic reaction was carried out for each catalyst sample for five hours in sunlight. This process was repeated thrice. The initial COD and COD after five hours were determined. It was found that there was no change in the photocatalytic activity of photocatalyst after using twice.

\section{Conclusion}

Strontium and Tin doped Zinc Sulphide and pure Zinc sulphide were synthesized by Sol-Gel method. The synthesized photocatalyst have nano sized hexagonal wurtzite structure confirmed by XRD analysis. The band gap of pure Zinc Sulphide $(3.7 \mathrm{eV})$ is lowered by doping it with $\mathrm{Sr}$ and $\mathrm{Sn}(3.2 \mathrm{eV})$ with enhanced photocatalytic activity. A PL spectrum shows the blue shift of doped Zinc Sulphide. The photocatalytic activity of Sr and Sn doped catalyst is better than pure Zinc Sulphide prepared by Sol-Gel method in UV light. 50 $\mathrm{mg} / 100 \mathrm{ml}$ is the optimum quantity for catalyst loading. Acidic $\mathrm{pH}$ favours the fast degradation Resorcinol. Sn and Sn doped Zinc Sulphide photocatalyst can be reused with retaining photocatalytic activity.

\section{Acknowledgement}

All the experimental work was supported by Dr. Babasaheb Ambedkar Technological University Lonere Raigad, SAIF, IIT Bombay and IIT Madras, India. This research did not receive any specific grant from funding agencies in the public, commercial, or not-for-profit sectors.

\section{Contribution of Authors}

The authors declare that this work was done by the authors named in this article and all liabilities pertaining to claims relating to the content of this article will be borne by them. Madhuri M. Bhagat carried out the research work. Dr.PB Lokhande and Dr.HA Mujawar supervised the whole research work. All authors have reviewed and approved the content of the submitted manuscripts.

\section{Conflict of Interest}

No conflict of interest is associated with this work.

\section{References}

1. Hahn S (2006) Concise International chemical assessment document. World Health Organization, Geneva.

2. Amaral MJJ (2002) The endocrine disruptors: a major medical challenge. Food Chemical Technology 40: 781-788.

3. Pouran SR, Aziz ARA, Daud WMAW (2014) Review on the advances in photo-Fenton oxidation system for the recalcitrant wastewater. J Ind Eng Chem 21: 53-69.

4. Pardeshi SK, Patil AB (2009) Solar photocatalytic degradation of resorcinol a model endocrine disruptor in water using Zinc Oxide J Hazard Mater 163: 403-409.

5. Pirhashemi M, Habibi-Tangjeh A, Pouran SR (2018) Review on the criteria anticipated for the fabrication of highly efficient $\mathrm{ZnO}$-based visible-light driven photocatalysts. J Ind Eng Chem 62: 1-25.

6. Lawless D, Serpone N, Meisel D (1991) Role of OH radicals and trapped holes in photocatalysis. A Pulse Radlolysls Study. J Phys Chem A 95: 5166-5170.

7. Zegeye DZ, Yadav OP, Mengesha AT (2017) Photocatalytic activity of $\mathrm{Mn}-\mathrm{N}$ co-doped $\mathrm{ZnS}$ nanoparticles for the degradation of organic pollutant (Methylene Blue). IJPSR 1: 39-50.

8. Hamendez-Ramirez A, Medina-Ramirez I (2015) Photocatalytic semiconductors synthesis, characterisation and environmental applications. Springer International Publishing, New York. p. 289.

9. Mukherjee A, Mitra P (2015) Structural and optical characteristics of SnS thin film prepared by SILAR. Mat Sci 33: 847-851. 
Citation: Bhagat MM, Lokhande P, Mujawar HA (2018) Effect of Tin and Strontium Doping on the Photocatalytic Activity of Zinc Sulphide Nanoparticles for the Photocatalytic Degradation of Resorcinol under Solar and Ultra-Violet Light. J Nanosci Curr Res 3: 122. doi: $10.4172 / 2572-0813.1000122$

Page 7 of 7

10. Bhagat MM, Lokhande PB, Mujawar HA (2017) Photocatalytic degradation of carcinogenic rhodamine $6 \mathrm{~g}$ dye by strontium and tin doped cadmium sulphide nanoparticles. IJRPET 3: 129-136.

11. Xua C, Deb S, Baluc AM, Ojedad DM, Luqued R (2015) Mechanochemical synthesis of advanced nanomaterials for catalytic applications. Chem Comm 31: 16.

12. Jiang D, Cao L, Liu W, Su G, Qu H, et al. (2009) Synthesis and luminescence Properties of Core/Shell $\mathrm{ZnS}: \mathrm{Mn} / \mathrm{ZnO}$ Nanoparticles Nanoscale Res Letter 4: 78-8.

13. Fang, XS (2011) ZnS nanostructures: from synthesis to applications. Prog Mat Sci 56: 175-287.

14. Tolia JV, Chakraborty M, Murthy ZVP (2012) Photocatalytic degradation of malachite green dye using doped and undoped $\mathrm{ZnS}$ nanoparticles. Pol J Chem Tech 14: 16-21.
15. Tang WZ, Huang CP (1995) Inhibitory effect of thioacetamide on CdS dissolution during photocatalytic oxidation of 2,4-dichlorophenol. Chemosphere 30: 1385-1399.

16. Wu X, Li K, Wang H (2009) Facile synthesis of ZnS nanostructured spheres and their photocatalytic properties. J Alloys Compd 487: 537-544.

17. Pouran SR, Bayrami A, Raman AAA, Daud WMAW, Shafeeyan MS, et al. (2018) Comprehensive study on the influence of molybdenum substitution on characteristics and catalytic performance of magnetite nanoparticles. Res Chem Intermed 44: 883- 900.

18. Khatae A, Hassandoost R, Pouran SR (2018) Cerium Substituted magnetite: Fabrication, Characterization and sonocatalytic assessment. Ultrason Sonochem 41: 626-640. 